\title{
Post-secular religious practices entering traditional religion
}

\section{Introduction}

Nowadays we can observe complex interactions between the religious and secular spheres. Several different processes take place simultaneously: the traditionally religious elements function in the secular sphere as if they were part of secular culture; elements of the secular sphere build a specific kind of post-secular religiosity; finally, this post-secular religiosity influences traditional religions. In this article I will focus on the last stage of these changes. My purpose is to describe and interpret the practices we can observe. Because of the complexity of this issue, I will limit my analyses to examples taken from the Catholic Church in Germany, where this process seems to be as popular as it is paradoxical. But before I present how the entry of post-secular religious practices into traditional Catholicism functions, with the possible reasons for and consequences of these changes, it is necessary to place it into a context of the two other stages mentioned above.

\section{From the religious to the secular sphere}

In the Western societies, the elements which we usually associate with religion have become separated from their original context; they move from the religious to the secular sphere. I call this phenomenon 'post-religious secular practices. It has three forms.

The first form is clearly visible in advertisements. They present a new kind of connection between religion and a variety of everyday activities which usually have no special religious meaning. This is a marketing strategy which aims at suggesting that consumption can satisfy the deepest personal needs which are usually satisfied by religion, such as, for example, the need for personal fulfillment, or a happy life. ${ }^{1}$ These religious associations obviously have 
nothing to do with any genuine religious practice. Nevertheless, they seem to replace religion with a secular alternative or, at least, give consumers the illusion that they can do so. The advertising slogans such as: 'Show yourself. Be yourself' (Smart phone Nokia N9), 'Because you're worth it' (L'Oréal), 'Just do it' (Nike), 'The power of dreams' (Honda), 'Driving is believing' (Hyundai), 'Open your mind' (Smart), 'Move your mind' (SAAB), encourage consumers to buy a car, a new model of mobile phone, use a particular brand of shampoo or lipstick, wear particular clothes, and so forth. There is a connection made between psychological needs and consumption. The hidden message is: possessing or using particular goods determines or proves that one belongs to a particular social group, brings one acceptance or prestige in the environment, makes one feel happy and fulfilled (Sobolewska 2009: 14-15). Another example is the character of Santa Claus, appearing for decades in Coca Cola advertisements. He is modelled on a real historical figure-Saint Nicholas, Bishop of Myra in Asia Minor, living in the fourth century and still celebrated in Orthodox Christianity. According to the tradition, Bishop Nicholas took particular care of the poor. Probably the only feature of Saint Nicholas that remains in the character of Santa Claus is that of giving selflessly: Coca Cola marketing specialists use this element to build an association between their product and the positive attitude of giving and sharing, with warm feelings and, obviously, with Christmas (Santa Claus appears in Coca Cola advertisements around Christmas time), which in Western societies is a festival of family, being together and sharing.

The second form of post-religious secular practice is a deliberate use of religious elements or associations in order to attract the attention of consumers by means of provocation. One of the examples might be an advertising poster for Pirelli, referring to the monumental statue of Christ in Rio de Janeiro. The poster shows the panorama of Rio de Janeiro with the place of the Christ statue in the middle. The picture of Rio looks as if it was taken from behind the statue, showing it from the back. But in the place of the statue there is the top Brazilian footballer Ronaldo, imitating Christ's pose. The association with the religious (and in this case also a national) symbol is more than obvious.

The third form of post-religious secular practice I would like to mention is a secular use of former religious objects. Because of the decrease in the number of church visitors in Western Europe, many churches which are no longer used for religious assembles are turned into secular objects, such as restaurants, pubs, stores. For instance, the former St Mary Church in Dublin is nowadays a restaurant, while the Paradiso Club in Amsterdam, similarly, was also once a church. 


\section{From the secular sphere to a specific kind of religiosity}

I qualify the movement from the secular sphere to a kind of religiosity among the post-secular religious practices. What does the term 'post-secular religious practices' actually stand for? In a society which claims to be secular there appear forms of spirituality, expressed by a concern for integral personal development as the main goal-including body, mind, inwardness and harmony with other people and nature. These make for what is usually called 'well-being. Such forms of spirituality appear in the space previously filled by traditional religious practices, which also gave the individuals the opportunity to gain personal integrity. Thus, well-being practices with all the associated means of supporting or enabling people to achieve well-being-food, clothes, books on good nutrition or personal development, alternative medicine, coaching, workshops on yoga and so forth-are a significant element of postsecular religious practices. It is not to be overlooked that well-being makes for a lifestyle and has impact on the economy-well-being services constitute a huge market. The market enters the spiritual realm and spirituality appears on the market, as it becomes a consumer good: consumers pay for the means to a positive spiritual experience, healing and strengthening the body (Davie 2007: 230-1).

The word 'post' in the term 'post-secular religious practices' does not mean 'after' in the sense of some new era replacing the age of secularism. We cannot observe such a change; rather we notice traditional religions and secularism co-existing simultaneously. The post-secular religious practices, as I understand them, represent forms of spirituality which are making an appearance in the secular context, where no religious practices were present before. At the same time, the society participating in these practices does not cease to claim to be secular. This post-secular spirituality is not a return, or a conversion to a traditional, established religion such as Christianity or Islam-that is an important aspect of the post-secular religious practices. It seems that in this particular context the term 'religious' can mean any kind of spiritual activity. But to what extent is it appropriate to talk about religiosity with respect to the well-being practices? Does religion require a reference to some transcendent reality, or doesn't it? Can these post-secular religious practices create an alternative to secularism? These are questions which cannot be answered in this short article, but will have to be asked in further research on post-secular religious practices. Even though that is not a very precise term, at the moment we have no better one, which could describe this phenomenon. On the other hand, the term is clear enough to be used in this analysis. However, because 
of the aforementioned problems with the definition of the post-secular religious practices, in this article I will use this term as relating to the examples in which the religious aspect is explicitly present.

\section{From post-secular religiosity to traditional religion}

Having briefly shown the interactions between secular and religious spheres, I can now proceed to the analysis of the main topic of this article: post-secular religious practices which are entering the traditional religions. As it was mentioned in the introduction, I focus on the example of the Catholic Church in Germany. However, similar processes also occur in other Christian communities.

\section{The phenomenon itself}

Many Catholic communities offer their members, as well as people they want to attract, forms of spiritual support which exceed the traditional Christian practices (by the latter I mean for example meditation on the Gospel, worship, the liturgy, the sacrament of Confession). They offer spiritual health and wellbeing practices as we know them from post-secular spirituality, for example, yoga, mindfulness, healthy nutrition. This phenomenon may have two forms: the new post-secular elements are introduced and integrated into the old, traditional Catholic practices, or the traditional Catholic elements are changed into forms of 'post-secular' ones.

Let me present three examples. The first one is the Zen courses offered in some Benedictine centres as a part of the heritage of meditation-according to the organisers they are essential for everyone, independently of the religious and cultural context. The most prominent representative of this stream in Germany is a Benedictine, Father Willigis Jäger, who led the Benediktushof spirituality centre until his retirement in $2007 .{ }^{2}$ According to its web page, the centre offers courses and workshops on Zen and Christian contemplation as ways of leading individuals to answers to their existential questions. The centre wants to be religiously neutral. But does it really work? The centre sells workshops on Zen, originally an integral part of Buddhism, under a Christian label-the place is a former Benedictine monastery, founded in the eighth century, as is emphasised by the leaders of the centre. The approach to 2011). 
Christian contemplation is questionable from the theological point of view. According to the centre leaders, contemplation is something individuals can learn on courses in the same way they might learn any other skills they want to acquire. The centre's web page informs us: 'Following the tradition of Christian mysticism practised over centuries, contemplation involves first and foremost sitting in silence, with mindful walking, one-to-one conversations, body prayer and incantation as further elements. ${ }^{3}$ This approach is actually not to be reconciled with Christian understandings of contemplation, which the Christian theology describes as a gift from God to a human being having a deep relationship with him. Therefore it is not something that could be reached by sitting in silence or mindful walking.

The offer of Benediktushof is a typical example of the phenomenon explored in this article. On the one hand, the post-secular religious practice, which is the Zen meditation extracted from its original religious background and treated merely as a method of meditation, an exercise for body and mind, enters the Christian context, which is the prayer and meditation tradition of the old Benedictine monastery. On the other hand, the practices of Christian contemplation and mysticism are reduced to post-secular forms, since they are presented (separated from the whole mystic tradition) as something everyone who seeks internal silence, balance and peace can learn on workshops, independently of the religious background. However, the Willigis Jäger's centre distinguishes between Zen meditation and Christian contemplation, while for example the Benedictine Abbey at Beuron offers seminars on 'Christian Zen-Meditation': 'The courses employ the old Christian tradition of prayer in silence and stimulation by Eastern experiences (Zen-style).4 The combination offered at Beuron seems very questionable from both Christian and Buddhist points of view. There are two fundamental problems with such an amalgam. Firstly, Christian anthropology is different from the Buddhist one. According to Christian anthropology the human being is created by God as a unique being, endowed with the vocation to a personal relationship with God himself; the identity of each human being is different from the divine one and remains so forever, even after death, because the final aim of human existence is resurrection. For Buddhism a human being is one of many incarnations of the element belonging to the absolute principle of the universe. The aim of 2011).

4 http://www.erzabtei-beuron.de/quelle/exerzitien.php\#meditation (accessed on 27 October 2011, my translation). 
human existence is to liberate this element from the body and let it return to the absolute. There is no idea of a preservation of any individual identity. Secondly, meditation is closely connected to anthropology-if human existence, according to each of the two religions, has different aims, meditation has different sense as well. The purpose of Christian meditation is to meet interpersonally the living God, whereas Buddhist meditation is a step on the path to unity with the Absolute in order to break free from the cycle of incarnation. Actually, the combination of Zen and Christian meditation is impossible at the doctrinal level and therefore also at the practical level. Otherwise it would mean a loss of the specific features of the both elements-the Christian and the Buddhist one.

Another example concerns the spiritual exercises of St Ignatius of Loyola, a programme of spiritual retreat based on meditation on the Gospel and on a personal relationship the participant has with God. The purpose of Ignatian exercises is to discover one's vocation, to make important decisions, or just to intensify one's religious life. What is offered nowadays under the label 'Ignatian exercises'? As an example, the web page of the spirituality centre in the diocese of Mainz reads as follows: 'The participants should perceive their life, their environment, but also the Gospel with all senses. The body experiences-for example euphony or yoga-and the attention paid to the feelings, impressions and psychological condition are integral parts of the exercise course. 5 In practice the meditation on the Gospel may be immensely reduced. Instead of helping with the meditation of the Gospel, the person leading the retreat introduces relaxation exercises and other activities for increasing the awareness of the body and senses. These practices and the emphasis on psychological conditions do not belong to the Ignatian spiritual tradition, but they rather constitute elements of the well-being practices. What happened to the exercises of Ignatius in their modern German version is par excellence an introduction of post-secular religious practices into a traditionally Catholic practice.

The next example is the fascination with Hildegard of Bingen. This Benedictine nun, living in the twelfth century, was one of the most influential women of the Middle Ages. She was a mystic, composer and writer, but today Hildegard is associated rather with her natural medicine methods and healthy cuisine than with her spiritual heritage. The church institutions themselves contribute to this situation by offering workshops and courses on fasting and 
good nutrition as practised by Hildegard. The religious aspect of fasting is present only in the background. The main purpose of these events, open not only to engaged Christians, is the harmony of body and mind; in other words, well-being - as for example during the fasting week for women according to the methods of Hildegard which is offered by the diocese of Freiburg. ${ }^{6}$

However, the popularity of Hildegard's healing practices reaches beyond the scope of the Church. To some extent, Hildegard undergoes the same process as mentioned above in the case of Saint Nicholas; she becomes a master of the healing diet, offered among many others, ${ }^{7}$ and a brand name for good nutrition, independent of, or even in isolation from her other religious activities. Some manufacturers and shops are specialised in 'Hildegard's' products-for example spelt, which is the basis of good nutrition according to Hildegard, or different types of herbal tea or spices. One of the companies advertises itself on the web page as 'the only manufacturer of the authentic Hildegard products. ${ }^{8}$

\section{Causes}

The most interesting question is: why do the Catholic communities integrate these post-secular practices into traditional religiosity, or let their own traditional features become a kind of post-secular practice? Did they cease to find in their own tradition the resources for reaching inner harmony and spiritual health? Why do they look for these resources beyond their own spheres, or why do they try to appear not (only) as one of the biggest religious traditions, but also as one of the suppliers of well-being? I identify two kinds of cause for this situation, which are both closely connected-causes which can be identified as being outside the Catholic Church and those which are present within. The Church is a part of society, therefore influenced by it. It experiences internal changes, which are partially consequences of the interpretation of its own sources, continually renewed across the centuries, and partially as a reaction to the changes in the world around it.

6 http://www.erzbistumfreiburg.de/html/aktuell/aktuell_u.html?t=\&\&cataktuell=955\% 7C957\&m=24400\&artikel=9404\&stichwort_aktuell=\&default=true $($ accessed on 25 October 2011).

7 See e.g. the offer of the non-medical practitioners: http://www.richtig-heilfasten.de/ hildegard-von-bingen-fast en.html (accessed on 25 October 2011).

8 http://www.hildegard.de/ (accessed on 25 October 2011, my translation). 


\section{Causes outside of Catholicism}

The first cause is consumer culture. Consumer culture is a way of life which involves buying and selling goods or services. It may be defined as 'social arrangement in which the relations between lived culture and social resources, between meaningful ways of life and the symbolic and material resources on which they depend, are mediated through markets' (Arnould 2006: 605). The consumer culture concerns everybody-both non-religious people and church members. It influences religiosity by making it more superficial. Religious beliefs, symbols and practices are turned into abstract elements which can easily be extracted from their original religious context and function as if they are separated from this context ${ }^{9}$ (Miller 2003: 29-30).

The attitude of the consumer society takes in religion, which becomes one of the goods available for helping one to discover one's real identity; to achieve harmony with God (in whatever sense the term 'God' might be used) and with other people. Such a religion does not require any effort, sacrifice or conversion. It is just something that makes people feel better; one among a number of other spiritual therapies.

Just like religious desire, consumer desire represents a typically human longing for something more-neither of them can be satisfied. Actually, the two desires have the same root, but different objects. In the Christian tradition, this unlimited desire should be redirected from the earthly sphere to God, who is the only one able to fulfil it (contrary to the earthly goods). In case of the consumer desire this redirection does not occur. Instead, the desire keeps seeking its fulfillment in new goods-material objects, power, fame, career, delight. The hope of finding fulfillment some day is stronger than the past experience of not having been able to find it yet (Miller 2003: 126-8).

Consumer culture also presents another interesting paradox. Most modern consumers would agree that charity works are something good and necessary in our world (the Catholic Church in Germany is famous for this kind of activity). But how to bring together consumption and charity? Is it part of an authentic will to do something selflessly or is it rather merely one of the ways available to a consumer to feel better? An individual can make a money transfer to a charity organisation in order to consume this positive feeling of having done a good thing. ${ }^{10}$

10 For similar paradoxes see Miller 2003: 16-19. 
The second external cause of religious practices entering traditional Catholicism is that religion becomes an object of individual choice. This process is very clearly noticeable in the United States. It is described by the rational choice theory (RCT): 'The theory itself is relatively simple: it postulates that individuals are naturally religious (to be so is part of the human condition) and will activate their religious choices, just like other choices, in order to maximize gain (however conceptualized) and to minimize loss' (Davie 2007: 69). According to Grace Davie, RCT is as crucial for the United States as is the secularisation theory for Europe. Davie claims that in Europe thinking about the church (and religion generally) as an institution is still present in both the church and society. Therefore the category of institutional affiliation matters for the church members. Europeans do not see their religious institutions as enterprises competing for customers on a spiritual marketplace, but as institutions for the common good (Davie 2007: 12). But on the other hand, the tendency to believe without institutional belonging increases in Europe. Thus the tendency to choose freely any form of religiosity appears there as well (Davie 2007: 76). More and more people leave the church in order to gain more space for individual spirituality. This trend was emphasised by about 240 German (or German speaking) professors of Catholic theology who signed a 'Memorandum' calling for urgent reform of the Church in February 2011. ${ }^{11}$ Catholicism is more often associated with an institution than with spiritual life. It also might be the reason for which people living in Germany, a country where the Christianity is the major religion, ${ }^{12}$ seek spirituality outside of Christianity, for example in Buddhism or esotericism.

The popularity of esotericism, which includes a mix of religious elements, superstitions, spiritualism, meditation and therapies for body and mind, is the third cause of the aforementioned process. This stream becomes very strong on the spiritual market (not only as an idea, but also as good business in the form of the books and diverse artifacts or workshops on sale). This esotericism is seen as being in very serious competition with the Church in the field of spiritual and physical healing, or the experience of salvation, liber-

11 http://www.memorandum-freiheit.de/ (accessed on 26 October 2011).

12 In 2006 in Germany, a country of 83.27 million inhabitants, there were 25.7 million Catholics, 25.1 million Lutherans, 1.5 million members of Christian free churches, 1.4 million Orthodox Christians, 23.8 million people with no religious belonginga number almost as high as each of the two biggest churches. 4.77 million were subordinated to other religions-Judaism, Islam, Hinduism, Buddhism, new religions, esotericism. Religionswissenschaftlicher Medien- und Informationsdienst e.V. http:// www.remid.de/index.php?text=info_zahlen_grafik (accessed on 25 October 2011). 
ation and any kind of spiritual support. It has already influenced the thinking of Church members-for example there are Catholics who do not see any contradiction between the hope for reincarnation and a belief in resurrection (Claussen 2006: 134-6).

The fourth cause is the very popular idea of personal development which is connected to contemporary individualism. This idea can be considered to be an integral part of well-being practices. Its purpose is to grant an individual a harmonised, integrated personality, to be able to reach the most important life goals (professionally as well as personally) by means of coaching and personal training. The number of people interested in using these practices, as well as those offering the practices continues to increase. Personal development appears on the spiritual market as a secular idea. It is focused on the individual, with no relation to God, or any transcendent reality. It does not mean that the idea of personal development itself is foreign to the religion, even though it is expressed in different terms. The secular term of personal development could be used to describe spiritual growth in its Christian meaning-including personal integrity, living in a deep relationship with God and other people, developing personal virtues and struggling against weaknesses (sins). But Christianity and the Catholic Church are hardly ever associated with the opportunity for personal growth.

\section{Causes inside Catholicism}

The first cause inside Catholicism for the offering of well-being practices by Catholic institutions is the understanding of the Church's mission. The mission of the Church according to herself is to proclaim the Gospel and gain new disciples of Christ (Matthew 28:19). Therefore it means that the Church grows by gaining new adherents. Today we no longer see such a rapid growth of the Church as in the first centuries of her existence; on the contrary, in Western Europe the Catholic Church is losing members. In the case of Germany the number of Catholics who have decided to leave the Church has doubled in the last three years. ${ }^{13}$ Thus the concern of the Church is nowadays not only to follow the words of Jesus in order to gain new disciples, but also to retain a potentially high number of the present members. Among the German Catholics the longing for full churches; thinking of the Church in number categories, is still present, even though notable voices say that it is quality, not quantity that matters. In Germany the number of Church members is also important for another reason, which has nothing to do with evangelisation. 
The Catholic (as well as the Lutheran) Church in Germany is financed from obligatory taxes paid by citizens who declare their belonging to the Church. The decrease of members can lead in the future to significant financial problems for the Church.

Consciously or unknowingly, the Catholic Church becomes a part of the spirituality and well-being market and struggles for 'customers'. This struggle is crucial, not only for spiritual, but also for economic survival. In this struggle the church tries to show that Catholicism is not a burden but a support, that it can provide substantial benefits and that it represents not only an old, historic tradition, but that it could be topical and attractive for modern people. The inclusion of post-secular well-being practices into the church's 'offer' constitutes one aspect of this attitude. Paradoxically, this process in the Church in Germany does not mean that the Church would be really ready to become just one of a number of possible options on the spiritual market.

Another reason for well-being practices gaining supporters in the Church is the contemporary way in which the Catholic liturgy is celebrated. For many Catholics the liturgy seems to be incomprehensible, fossilised and monotonous. On the one hand, especially the lay Catholics complain that the liturgy offers them too few possibilities to engage and has no connection to their everyday problems; they understand the liturgy as old-fashioned ritual. On the other hand, the priests seem to have lost the sense of the liturgy-they do not explain the meaning of liturgical symbols and gestures, fail to point to the connections with everyday life which could be found in the liturgy. The wellbeing practices seem to offer more in this area-they refer to the practical aspects of life and allow for various forms of personal engagement.

\section{Consequences for Catholicism}

The entry of the post-secular religious practices into traditional Catholicism in Germany is very interesting for research, not only as a single phenomenon in the Church practice, but also because it is connected to the self-understanding of the Church and her attitude towards her own tradition. In other words, it exposes ongoing complex changes inside the Church. The fact that the post-secular practices can be attractive for the Church has several causes, as has been presented above. Yet, if that phenomenon is perceived together with other changes taking place in the Church, the consequences arising from the current situation will be remarkable.

We can observe that Catholicism loses its specific features, becomes more and more similar to the world surrounding it as a result of a simplification or the elimination of some of its traditions and practices on the one hand and 
by offering practices which are also offered outside the Church (often without any requirement of institutional affiliation and obligations, which can be seen as an advantage) on the other hand. Although bringing the post-secular practices into the Church is not the exclusive cause of this process, it is strengthened by such practices.

Let me point to two examples from the German Church of the loss of her specific features. The first and maybe the most remarkable example is the liturgy. As I mentioned above, many Catholics are no longer aware of its complex meaning. Therefore, for example, some prayers (e.g. the Lamb of $\mathrm{God}$ ), are being removed from the Mass as unintelligible. Often, one of the readings from the Bible is also removed or replaced by some other texts or a longer sermon. Another example could be the fact of neglecting one of the crucial topics of Christian faith-reconciliation and forgiveness connected to the Christian notion of sin. The principle of reconciliation appears at the social and political levels (e.g. reconciliation between Germany and Poland, or Germany and France after World War II), but in reference to the personal relationship between God and man, or among people, it is almost absent. The Sacrament of Confession, which according to the Catholic faith is an opportunity to reconcile with God and receive his forgiveness, disappears from German Catholic churches because more and more people (including the priests) cease to regard it as important as it used to be a few decades ago.

Since the Second Vatican Council, openness towards the contemporary world and dialogue with it has been one of the leading ideas of the whole Catholic Church. ${ }^{14}$ One of the aims of the Council was to make the Church's message more understandable and topical to modern society. However, this openness, according to the Council, does not ever mean a loss of specific Catholic features. Adapting the well-being practices, as we know them from the post-secular context, or modelling the Church's own traditional elements to forms of such practices, may be seen as an example of that openness and dialogue, but it can also bring a risk for the clarity of the Church's mission which should be-according to her own sources-the proclamation of the Gospel.

The time when the Catholic Church played a leading social, political and cultural role in Europe has definitely passed. Therefore the Church looks for a new role and new ways of presenting herself in the society-it is comprehen-

14 The most significant document of the Council concerning this matter is the Pastoral Constitution on the Church in the Modern World 'Gaudium et spes' from December $7,1965$. 
sible and belongs to the church's self-understanding according to the Council. As I mentioned above, Catholicism becomes just one of the offers on the spiritual market-it is undergoing this process, regardless of the fact that it is not in accordance with the purpose of the Church itself. When the Church ceases to be an obvious part of society, or to represent an obvious world-view, it can create a question mark (Claussen 2006: 40-1), but only if it retains its identity.

The Catholic Church assesses consumer culture negatively. Pope John Paul II expressed his concern about the consumer lifestyle in his Message for the Celebration of World Peace Day in $1999 .{ }^{15}$ Theologians also criticise consumer culture-from a practical perspective, as a social phenomenon (Gay 1998), or from the ideological aspect (Ward 2000, Long 2000). In my opinion, one of the tasks for the Church today is to analyse deeply consumer culture, not only seeing it as a negative phenomenon, but also as a new circumstance the Church has to face. Then the 'offer' has to respond to this new situation.

I also think that another important task for the Church ministry nowadays is to realise who are the people coming to the church, as well as who those remaining on the outside are. What do they look for? Do they really seek what the church 'offers'? In the United States we can talk about a generation of seekers-people who appreciate experience rather than faith, who look for individual fulfillment, who do not trust religious institutions, although they long for a community which would suit them; at the same time, they negotiate the conditions and limits of their religious affiliation before they engage and they do not hesitate to change their affiliations (Roof 1993: 8, 259-60). There are seekers in Germany as well. The well-being practices implemented into the Church's 'offer', which are not directly connected to the Catholic tradition, can somehow meet their needs, because they are not as binding as, for example, the Sacraments. But do these practices make it possible for the Church to present the Catholic tradition and faith as they really are? What will happen to those who want to learn something essential about Catholicism? Will they find the answers they look for?

15 http://www.vatican.va/holy_father/john_paul_ii/messages/peace/documents/hf_jpii_mes_14121998_xxxii-world-day-for-peace_en.html (accessed on 26 October 2011). 


\section{Conclusion}

The issue of this article is the phenomenon of the post-secular religious practices entering traditional Catholicism, shown in the example of Germany. An exhaustive analysis was impossible in such a short form, but the aim of the article is actually to sketch the phenomenon itself with its complex causes and possible consequences.

It is clearly visible how paradoxical the situation of the post-secular society is. People are looking for some kind religiosity or spirituality. Catholicism realises that the post-secular forms of religiosity are very popular and that many people choose them instead of the traditional Church. It could offer them spirituality based on ages of experience. But instead of making its own spiritual tradition competitive on the spiritual market, Catholicism seems to offer Christianised post-secular goods, or its own traditional elements represented in a secularised form. It seems difficult to predict how it will all end. However, we observe an interesting encounter and interaction between an 'old' religion and a new religiosity, which will certainly have impact on further presence of the Church in the society.

\section{Bibliography}

\section{Arnould, Eric J.}

2006 'Consumer Culture Theory: retrospect and prospect.' European Advances in Consumer Research 7 (1): 605-7. http://www.acrwebsite.org/volumes/eacr/ vol7/EuropeanVolume7 _105.pdf (accessed on 18 October 2011).

Claussen, Johann Hinrich

2006 Zurück zur Religion. München: Pantheon Verlag.

\section{Gay, Craig}

1998 'Sensualist without heart: contemporary consumerism in light of the Modern Project.' In: Rodney Clapp (ed.), The Consuming Passion: Christianity and the Consumer Culture. 19-39. Downers Grove, Illinois: Inter Varsity Press.

\section{Davie, Grace}

2007 The Sociology of Religion. Los Angeles, London, New Delhi, Singapore, Washington, DC: SAGE Publications.

\section{Long, D. Steven}

2000 Divine Economy: Theology and the Market. London: Routledge.

\section{Miller, Vincent J.}

2003 Consuming Religion: Christian Faith and Practice in a Consumer Culture. New York, London: The Continuum International Publishing Group Inc. 
URSZULA PĘKALA

\section{Roof, Wade Clark}

1993 A Generation of Seekers: The Spiritual Journeys of the Baby Boom Generation. San Francisco: Harper.

\section{Sobolewska, Anna}

2009 Mapy duchowe współczesności. Co nam zostało z Nowej Ery? Warszawa: Wydawnictwo W.A.B.

\section{Ward, Graham}

2000 Cities of God. London: Routledge. 